\title{
Modelling small-scale coastal fisheries of Galicia (NW Spain) based on data obtained from fisheries: the case of Sepia officinalis
}

\author{
FRANCISCO ROCHA ${ }^{1}$, JAIME OTERO ${ }^{2}$, RAQUEL OUTEIRAL ${ }^{2}$, \\ ÁNGEL F. GONZÁLEZ ${ }^{2}$, JOAQUÍN GRACIA ${ }^{2}$ and ÁNGEL GUERRA ${ }^{2}$ \\ Grupo Zoología Marina, Dep. Ecología y Biología Animal, Universidad de Vigo, Campus as Lagoas-Marcosende, \\ 36310 Vigo, Spain. \\ ECOBIOMAR, Instituto de Investigaciones Marinas (CSIC), C./ Eduardo Cabello 6, 36208 Vigo, Spain. \\ E-mail: frocha@iim.csic.es
}

\begin{abstract}
SUMMARY: The small-scale cuttlefish (Sepia officinalis) fishery in Galician waters (NW Spain) was studied using a model based on data obtained from fishers. This model was applied using information obtained from the small-scale Galician fleet in 1998. A total of 139 personal interviews were carried out at 62 Galician ports. This information was used to estimate catches per unit effort (CPUE) and total catch for the cuttlefish gillnet fishery. The fleet, which fishes in Galician waters within ICES divisions VIIIc and IXa, was composed of two groups: 600 vessels fishing for cuttlefish in only five months of the year (short season: November to March), and 141 vessels fishing for cuttlefish all year (extended season). Estimated total catch during the fishing season for the whole Galician fleet was $1301 \mathrm{t}$ ( $869 \mathrm{t}$ short season and $432 \mathrm{t}$ extended season) and average CPUE values were $14.5 \mathrm{~kg} \mathrm{haul}^{-1}$ trip $^{-1}$ vessel $^{-1}$ (short season) and $12.8 \mathrm{~kg} \mathrm{haul}^{-1}$ trip $^{-1}$ vessel-1 $^{-1}$ (extended season). To test the reliability of the model, the outputs obtained from the model for a subset of 37 ports $(59.7 \%$ of all ports) were compared with the official catch statistics for these ports. Differences between total catches estimated by the model and those determined directly at these ports were not significant.
\end{abstract}

Keywords: Sepia officinalis, small-scale fisheries, catch and CPUE estimations, Gómez-Muñoz model, NW Spain.

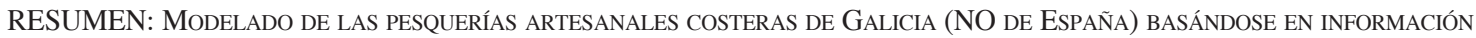
OBTENIDA DE LOS PESCADORES: EL CASO DE SEPIA OFFICINALIS. - La pesquería artesanal de enmalle de sepia (Sepia officinalis) en aguas de Galicia (NO España) se estudió usando un modelo basado en la información obtenida de los pescadores locales. Este modelo utilizó los datos obtenidos por entrevistas a pescadores para estimar las capturas por unidad de esfuerzo (CPUE) y capturas totales en la pesquería artesanal de enmalle de sepia (Sepia officinalis) en Galicia durante 1998. Un total de 139 entrevistas fueron realizadas en 62 puertos. Esta pesquería esta compuesta por embarcaciones que operan en la costa de Galicia (divisiones del ICES VIIIc y IXa). La flota se divide en dos grupos: uno formado por 600 embarcaciones que opera cinco meses al año (temporada corta, entre noviembre y marzo), y un segundo grupo de 141 embarcaciones que pescan todo el año (temporada extendida). El modelo estimó que la captura total en 1998 fue de 1301 t ( 869 t para la temporada corta y 432 t para la temporada extendida), con CPUE de $14.5 \mathrm{~kg}$. lance- viaje $^{-1}$ barco $^{-1}$ y de $12.8 \mathrm{~kg}$ lance- viaje $^{-1}$ barco $^{-1}$ para las temporadas corta y extendida, respectivamente. Para evaluar la fiabilidad del modelo se obtuvieron y compararon las estadísticas de 37 puertos en los que opera la flota (59.7\%) con las estimaciones generadas para esas localidades. No se observaron diferencias significativas entre las capturas totales obtenidas por el modelo y las registradas en las Cofradías.
\end{abstract}

Palabras clave: Sepia officinalis, pesquería artesanal, estimación de capturas y CPUE, modelo de Gómez-Muñoz, NO España.

\section{INTRODUCTION}

The cuttlefish, Sepia officinalis Linnaeus, 1758 , is an important commercial resource in
European fisheries (Guerra, 1989; Wang et al., 2003). Its ecology has been recently reviewed (Guerra, 2006) and cuttlefish fisheries have been studied in Portugal (Coelho and Nunes, 
1989), Sicily (Jereb and Ragonese, 1989) and the English Channel (Madelaine and Aovad, 1989; Dunn, 1999; Denis and Robin, 2001; Wang et al., 2003; Royer et al., 2006). These studies have focused on the analysis of catches or the evolution of landings and effort over a long period of time. However, except for a local study on the cuttlefish fishery in the Ria of Vigo (Arnaiz et al., 2002), no major studies of the cuttlefish fishery have been made in Spanish waters due to the complexity of the artisanal sector (mainly in Galicia).

Galicia is the home of Europe's biggest fishing fleet (Rocha et al., 2004). Galician smallscale coastal fisheries show a great complexity and they have a strong socio-economic, cultural and ecological importance (see Freire and García-Allut, 2000). Small-scale fisheries operating along the Galician coast are multi-species and multi-gear, cephalopods (octopus, cuttlefish and squid) being among the most important resources exploited in this area. The small-scale Galician fishery of $S$. officinalis is an important socio-economic activity that, between 2000 and 2005, amounted to between 236 and 523 t per year, with a first sale value of over 2 million euros (Xunta de Galicia, 2005). This fishery uses several gears to catch cuttlefish, but the one most often used by fishermen is the gillnet, a multispecies gear (Durán-Neira, 1991; Arnaiz et al., 2002).

No specific management plans for cuttlefish exploitation are in place due to the great complexity of coastal ecosystems and the smallscale fisheries in Galician waters (Freire and García-Allut, 2000; Rocha et al., 2004). Since 1994 the Galician Government has developed a programme to collect complete fishery statistics for the artisanal sector (Xunta de Galicia, 2005). However, this database is incomplete and does not provide the standards of quality and the detail needed for effective management of the cuttlefish resource. At present, this resource is regulated only by a minimum legal size of $80 \mathrm{~mm}$ dorsal mantle length (ML), a maximum length of fishing gear of between 1.5 $\mathrm{km}$ (vessels < 2.5 GRT) and $4.5 \mathrm{~km}$ (vessels $>5$ GRT) and the prohibition of fishing activities at weekends.

In this context, alternative methodologies and models have been used variously to estimate catch and catch per unit effort (CPUE) in smallscale fisheries (Gómez-Muñoz, 1990; Pollock et al., 1997; Hoening et al., 1997; Kirchner and Beyer, 1999; Neis et al., 1999; Arnaiz et al., 2002; Otero et al., 2005; Young et al., 2006). Among these, Gómez-Muñoz (1990) developed a simple model to estimate catch and catch per unit effort (CPUE) in multispecies small-scale fisheries. This model has been applied in Galician small-scale fisheries for squid and octopus and larger scale fisheries for monkfish (Simón et al., 1996; Otero et al., 2005; Rocha et $a l ., 2004)$. The method involves an interview survey of fishing sector personnel (e.g. ship-owners, skippers, fishermen) to obtain the basic model parameter data, and the model generates estimates of CPUE and total catch for the fishery. In multispecies fisheries, this model can be used to determine individual species catches for a specific gear (Rocha et al., 2004).

This paper uses the Gómez-Muñoz model, as modified by Rocha et al. (2004), to evaluate the cuttlefish catch levels and fishery performance of the small-scale gillnet fishery in Galicia. The reliability of the model was tested by comparing catch estimates with data obtained from the fishermen's associations (cofradias, see Freire and García-Allut, 2000) and official statistics. Furthermore, we describe the particular characteristics of this socio-economically important small-scale coastal fishery.

\section{MATERIAL AND METHODS}

\section{Area of study and interview data}

The study area was the fishing grounds in which the gillnet fleet operates in coastal Galician waters (NW Spain), comprising parts of ICES divisions IXa and VIIIc (Fig. 1).

Preliminary visits to 62 ports of the Galician coast were made between January and April 1998 to establish contacts with the personnel at each port and to determine which of them recorded cuttlefish landings. A total of 139 personal interviews at 37 ports where cuttlefish are landed were conducted from April 1998 to September 2000. The interviews were carried out at those ports with the greatest numbers of vessels and the highest cuttlefish catch variabil- 


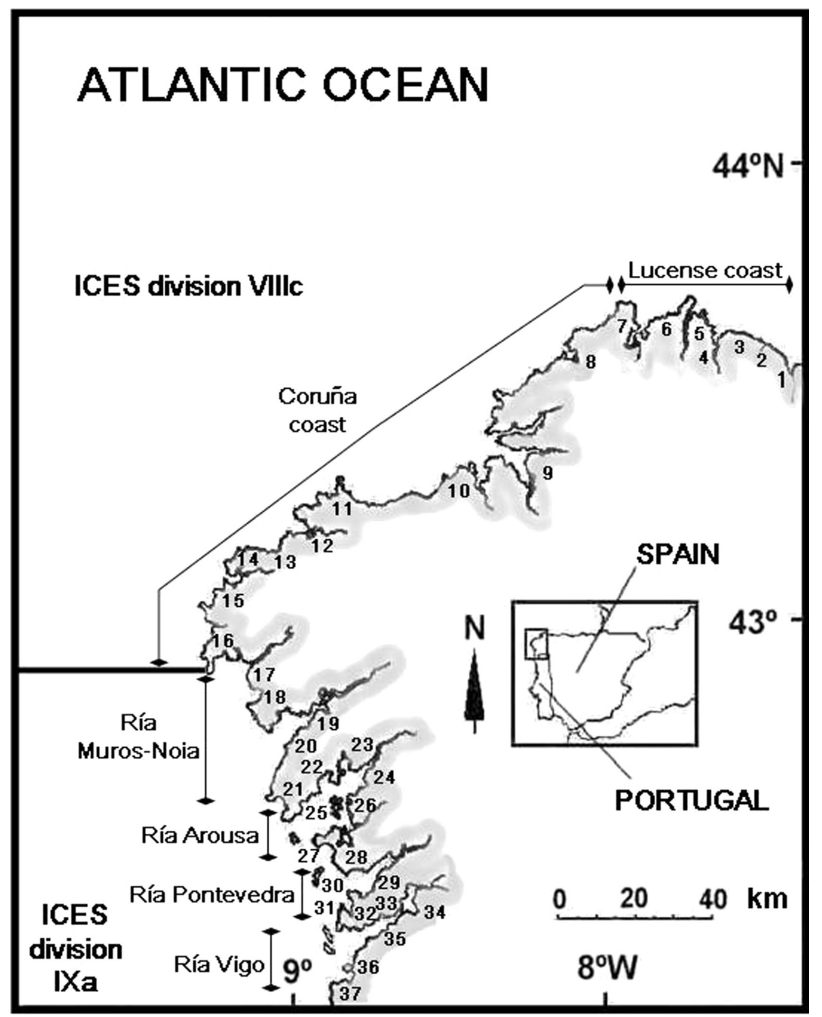

FIG. 1. - Study area (Galicia, NW Spain), showing the ICES divisions west VIIIc and north IXa. Map shows the coastal areas employed for comparisons. Numbers along the coast showing the location of the 37 Galician ports with cuttlefish catch statistics. A key with the name and number of these ports is included in Table 3.

ity. Interview data were analysed according to the length of the fishing season reported. The appropriate sample size (number of interviews, n) and the standard error (s.e.) were estimated following Rocha et al. (2004).

\section{The Gómez-Muñoz model}

The basic parameters required for input into the model were obtained from interview data according to the protocol described in Rocha et al. (2004), and are shown in Table 1. Outliers were identified and rejected as erroneous according to Rocha et al. (2004) following the statistical method of Tukey (1977).

A set of secondary parameters that depend on the type of decrease in catches (from maximum catch), which is determined from interview data, were estimated from the main parameters (see Rocha et al., 2004 and Table 1). The type of catch decrease was defined by its degree of asymmetry, measured by TE, which represents the relationship between the
TABLE 1. - Parameters estimated for the model for short and extended season Sepia officinalis gillnet fishery. Values of I: (1) slow catch decreased from the maximum; (2) intermediate catch decreased from the maximum; (3) rapid catch decreased from the maximum (Rocha et al., 2004).

\begin{tabular}{|c|c|}
\hline Model parameters & $\begin{array}{l}\text { Short } \\
\text { season }\end{array}$ \\
\hline
\end{tabular}

Month in which fishing starts (S)

Length of the fishing season, months (L)

Decrease curve type (I)

Month when the maximum catch is made $(\mathrm{M})$

Mean maximum catch $(\mathrm{kg})$ per haul $\left(\mathrm{C}_{\max }\right)^{*}$

Mean minimum catch (kg) per haul $\left(\mathrm{C}_{\text {min }}\right) *$

Number of hauls per trip (N)

Average number of trips per month per vessel v 20

\begin{tabular}{|c|c|}
\hline 11 & 3 \\
\hline 5 & 12 \\
\hline 2 & 1 \\
\hline 1 & 3 \\
\hline 29.49 & 18.50 \\
\hline 3.69 & 3.41 \\
\hline 1 & 1 \\
\hline 20 & 20 \\
\hline
\end{tabular}

* The interviewer asked for "mean" maximum and minimum catch in one haul $(\mathrm{kg})$ during the fishing season.

times elapsed (in months) from the start of the fishing season to the occurrence of maximum catch per haul $\left(\mathrm{C}_{\max }\right.$, Table 1$)$, and from this peak to the end of the fishing season (see Rocha et al, 2004 for details). To ensure that the month with maximum catch coincided with the origin $(x(M)=0)$ and to make the distribution more symmetrical, the data set was timetransformed $(\mathrm{x}(\mathrm{t}))$. This variable $(\mathrm{x}(\mathrm{t}))$ has different values for each month represented in the fishing season. The term 'month' was used to calculate $\mathrm{x}(\mathrm{t})$ in all cases, where $\mathrm{t}$ is the month of the year during the fishing season (e.g. for March $\mathrm{t}=3$ and for November $\mathrm{t}=11$ ). A timeweighting function $f(x)$ was estimated as a secondary variable that increases the weighting for the month of maximum catch $(\mathrm{M})$ and decreases it for the remaining months (Gómez-Muñoz, 1990; Rocha et al., 2004).

The mean monthly cuttlefish CPUE (in kg haul $^{-1}$ trip $^{-1}$ vessel $^{-1}$ ) for a vessel using a gillnet was estimated based on a uniform distribution, following the procedure described in Rocha et al. (2004), using the equation:

$$
\text { CPUE }=\frac{C_{\text {max }}(f(x(t))-f(I))+C_{\min }(1-f(x(t)))}{1-f(I)}
$$

In order to avoid the effect of negative values in the shape of the curve CPUE vs time, periods of 24 months were considered. The catch determination and the distribution of CPUE are described in the Appendix of Rocha et al. (2004). The standard error of the CPUE (s.e. ${ }_{\text {CPUE }}$ ) was calculated according to the equation: 


$$
\begin{gathered}
\text { s.e. }{ }_{\mathrm{CPUE}}=\left(\frac{\mathrm{f}(\mathrm{x}) \mathrm{f}(\mathrm{I})(\operatorname{maxCPUE}-\operatorname{minCPUE})}{\mathrm{n}+1}\right) * \\
*\left(\sqrt{\frac{\mathrm{nf}(\mathrm{I})^{2}-2 \mathrm{f}(\mathrm{I})+\mathrm{n}}{\mathrm{n}+2}}\right)
\end{gathered}
$$

where $\mathrm{n}$ is the number of interviews and $\mathrm{x}(\mathrm{t})$ was substituted by $\mathrm{x}$ to simplify the equation.

The total monthly cuttlefish catch per vessel $\left(\mathrm{C}_{\text {tot }}\right.$ in $\left.\mathrm{kg}\right)$ was estimated by the expression:

$$
\mathrm{C}_{\mathrm{tot}}=\mathrm{CPUE} * \mathrm{~N} * \mathrm{~V}
$$

where $\mathrm{N}$ is the mean number of hauls per trip and $\mathrm{v}$ is the mean number of trips per month (Table 1). The standard error of the $\mathrm{C}_{\text {tot }}\left(\right.$ s.e. $\left._{\text {Ctot }}\right)$ was calculated according to the equation:

$$
\begin{aligned}
\text { s.e. }_{\text {Ctot }}= & \left(\frac{f(x) f(I)\left(\operatorname{maxC}_{\text {tot }}-\operatorname{minC}_{\text {tot }}\right)}{n+1}\right) * \\
& *\left(\sqrt{\frac{n f(I)^{2}-2 f(I)+n}{n+2}}\right)
\end{aligned}
$$

Finally, the total catch (CT in $\mathrm{kg}$ ) for the fishing fleet over the entire fishing season at each port was estimated as follows:

$$
\mathrm{CT}=\left(\sum_{1}^{\mathrm{L}} \mathrm{C}_{\mathrm{tot}}\right) * \mathrm{~B}
$$

where the summation goes from the month in which the fishing season starts to the end of fishing period, and B is a parameter that converts the modelled fishery into a mono-species fishery. The B parameter represents the number of vessels in the fleet that are exclusively targeting cuttlefish using gillnets. As the small-scale fleet is characterised by being multi-gear, and due to the lack of information about a precise schedule that describes when a vessel is using each gear, B was estimated using the information gathered from the official census for 1999 (Xunta de Galicia, 2000). Thus, the number of "virtual" vessels exclusively targeting cuttlefish was estimated by considering the number of gear types which each vessel can use (number of gear registered), and assuming that a vessel expends equal fishing effort with each gear type (i.e. a vessel with two different registered gears has a value of 0.5 ). Then $\mathrm{B}$ was estimated by adding up the number of virtual cuttlefishfishing vessels in each port according to:

$$
\mathrm{B}=\sum_{\mathrm{i}=1}^{\mathrm{n}} \frac{\text { Vessel }_{\mathrm{i}}}{\mathrm{N}^{\mathrm{o}} \text { of gear types which " } \text { Vessel }_{\mathrm{i}} \text { " can use }}
$$

\section{Comparison with official statistics}

To test the fitting of the model, the estimated catches for 1998 were compared with the available official data in ports during 1998. First, the monthly total catches estimated by the model were compared with monthly official catch data in 37 Galician ports during 1998. Secondly, estimated total catches in each of those 37 ports were correlated with catch statistics from fishermen's associations (Cofradías) for 1998 considering each port and grouping them into the main coastal Galician areas. A $t$ test was then used to compare the significance of those differences (Zar, 1999).

\section{RESULTS}

\section{Description of the fishery}

In 1997, the Galician gillnet fleet comprised a total of 1856 vessels. However, according to fishermen, port databases and number of gears employed, only 741 vessels catch cuttlefish as a target species. According to the interview data, the fleet operates in numerous coastal embayments (known as rías), in waters of 5 to $30 \mathrm{~m}$ depth, and in shallow oceanic waters down to $200 \mathrm{~m}$ depth. The vessels range in size from 0.8 to 15.5 gross registered tons (GRT), with a mean of 2.4 GRT. The engine power ranges from 5 to 40 HP, with a mean of $21.5 \mathrm{HP}$, and vessel length ranges from 6 to $15 \mathrm{~m}$. The typical crew consists of two fishermen. The gillnet fishery is a multispecies activity. Cephalopods, fishes and crustaceans are fished together. Among cephalopods, cuttlefish is the most important species caught by gillnet.

Cuttlefish is fished in Galician waters near the coast or within the estuaries and the rías. Data from interviews were divided into two groups according to the length of the fishing season: vessels fishing cuttlefish only five months of the year (short season) and vessels 
TABLE 2. - Sepia officinalis monthly catch per unit effort (CPUE) in $\mathrm{kg} \mathrm{haul}^{-1}$ trip $^{-1}$ vessel $^{-1}$, and monthly catch $\left(\mathrm{C}_{\text {tot }}\right.$ in $\left.\mathrm{kg}\right)$ for the gillnet fishery estimated by the model. $\mathrm{C}_{\text {season }}$ : total annual catch for a vessel. s.e. ${ }_{\text {Ctot }}:$ standard error of the monthly catch. $\mathrm{CI}_{\mathrm{Ctot}}$ and $\mathrm{CI}_{\text {Cseason }}$ : confidence intervals for mean monthly and total annual catches, respectively.

\begin{tabular}{lcccc}
\hline & $\begin{array}{c}\text { Short season } \\
\text { CPUE } \\
\text { Monthly catch } \\
\left(\mathrm{C}_{\text {tot }}\right)\end{array}$ & \multicolumn{2}{c}{$\begin{array}{c}\text { Extended season } \\
\text { CPUE }\end{array}$} & $\begin{array}{c}\text { Monthly catch } \\
\left(\mathrm{C}_{\text {tot }}\right)\end{array}$ \\
\hline January & 29.5 & 589.8 & 5.5 & 110.4 \\
February & 17.7 & 355.0 & 3.4 & 68.2 \\
March & 3.7 & 73.8 & 18.5 & 370.0 \\
April & & & 18.3 & 366.8 \\
May & & & 17.9 & 257.4 \\
June & & & 17.1 & 342.0 \\
July & & & & 16.0 \\
320.9 & & & 14.7 & 294.7 \\
August & & & 13.2 & 264.0 \\
September & & & 11.5 & 229.4 \\
October & 3.7 & 73.8 & 9.6 & 191.8 \\
November & & 7.6 & 151.8 \\
December & 17.7 & 355.0 & & 255.6 \\
Mean & 14.47 & 289.5 & & 5.66 \\
S.e.Ctot & & 0.31 & & $246-266$ \\
CICtot & & $289-290$ & & 431918 \\
Cseason & & 868710 & & $415103-448732$ \\
CICseason & $866855-870564$ & & \\
& & &
\end{tabular}

fishing cuttlefish all year (extended season). The short season starts in November and this group is composed of vessels that use gillnets only in this period and other types of gears during the rest of the year. The extended season starts in March and this group is composed of vessels that use gillnets all year around. The gillnet fishery for cuttlefish is composed of 741 vessels registered at 62 Galician ports: 600 vessels fishing cuttlefish only five months of the year (short season: November to March), and 141 vessels fishing cuttlefish all year (extended season).

\section{Estimates based on the model}

A total of 139 interviews were carried out at 37 selected ports (Fig. 1). The interviews were distributed as follows: 109 with fishers operating over a short season and 30 with fishers operating over an extended season. The minimum sample sizes to obtain catch estimates with an error of $10 \%$ were 105 and 27 interviews for the short and extended seasons, respectively.

Table 1 lists the parameter values estimated for short and extended season gillnet fisheries for Sepia officinalis. Table 2 shows the CPUE, the monthly and total catches per trip, the mean catch $(\mathrm{kg})$ per haul and vessel $\left(\mathrm{C}_{\mathrm{t}}\right)$, and the

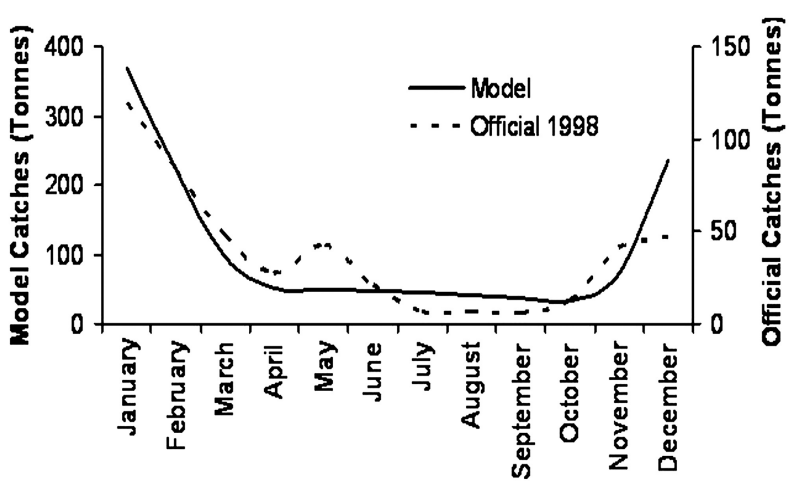

FIG. 2. - Comparison between total monthly model estimates and total monthly official catches in 1998 for cuttlefish gillnet fisheries. For model estimations monthly catches for both seasons were pooled together.

range and standard error of the mean. CPUE for the short season gillnet fishery, as estimated by the model, showed an intermediate rate of decrease at the end of the fishing season, with the maximum catch taking place in March, whereas CPUE for the extended season showed a slow decrease, with maximum catches occurring in January.

Based on estimations made by the model, and considering the number of vessels in each port, total catches for the two cuttlefish fisheries seasons were estimated. Total Galician catches were estimated to be $1301 \mathrm{t}$ (95\% confidence interval, CI: 1282-1320 t) divided into $869 \mathrm{t}$ (CI: 867-871 t) and $432 \mathrm{t}$ (CI: 415-449 t) for the short and extended seasons, respectively (Table 3 ).

To estimate total catches of the fleet, monthly catches of short and extended season vessels groups were summed. Estimated total catches from the model were significantly correlated $\left(\mathrm{R}^{2}=0.8239 ; \mathrm{p}<0.05\right)$ with total official catches reported for 1998 (Fig. 2).

Cuttlefish catch statistics were obtained from fishermen's associations (Cofradías) only in 37 (59.7\%) of the 62 Galician ports for 1998 (Table 3 and Fig. 3). If we group catches into the coastal areas shown in Figure 1, a high positive correlation can be observed between observed and predicted total catches (Figs. $3 b$ and $4 ; \mathrm{R}^{2}=0.9929$; $\mathrm{p}<0.05)$. Only the "Ría of Vigo" zone showed significant differences (Fig. 3b). A difference of $0.57 \%$ between catches estimated by the model and those obtained from the official data was found. This difference, which is not statistically significantly (chi-square $=0.017 ; \mathrm{p}>0.05$ ), represents 6.3 t of $S$. officinalis (Table 3 ). 
$598 \cdot$ F. ROCHA et al.

TABLE 3. - Mean total catches $(\mathrm{kg})$ in the inshore and offshore Sepia officinalis gillnet fishery estimated by the model for the whole Galician fleet. B: estimated number of vessels in each port. CT: total annual catch. Co: catches during 1998 obtained from official sources. Total ${ }_{37}$ : total values at 37 ports of the Galician cuttlefish gillnet fishery.

\begin{tabular}{|c|c|c|c|c|c|c|c|}
\hline \multirow[b]{2}{*}{ Ports } & \multicolumn{2}{|c|}{ Short season } & \multicolumn{2}{|c|}{ Extended season } & \multicolumn{2}{|c|}{ Total fishery } & \multirow[b]{2}{*}{ Co } \\
\hline & B & CT & $\mathrm{B}$ & CT & B & $\mathrm{CT}$ & \\
\hline A Coruña & 3.3 & 4802 & 1.7 & 5160 & 5.0 & 9962 & 61716 \\
\hline A Guardia & 3.0 & 4368 & 2.0 & 6081 & 5.0 & 10448 & 387 \\
\hline Aguiño & 24.9 & 36010 & 10.1 & 31044 & 35.0 & 67054 & 179 \\
\hline Aldan & 5.2 & 7505 & 8.8 & 27039 & 14.0 & 34544 & 518 \\
\hline Ares & 4.0 & 5790 & & & 4.0 & 5790 & \\
\hline Baiona & 13.7 & 19844 & 8.3 & 25429 & 22.0 & 45272 & 6264 \\
\hline Barallobre & 2.0 & 2895 & & & 2.0 & 2895 & \\
\hline Bueu & 23.0 & 33312 & 1.0 & 3020 & 24.0 & 36332 & 32964 \\
\hline Burela & 10.0 & 14531 & 5.0 & 15216 & 15.0 & 29747 & 17250 \\
\hline Caion & 4.3 & 6203 & 0.7 & 2191 & 5.0 & 8394 & \\
\hline Camariñas & 25.6 & 36983 & 1.4 & 4443 & 27.0 & 41426 & 1057 \\
\hline Cambados & 64.7 & 93574 & 3.3 & 10275 & 68.0 & 103849 & 51118 \\
\hline Camelle & 10.6 & 15382 & 2.4 & 7278 & 13.0 & 22660 & 8 \\
\hline Cangas & 36.3 & 52555 & 10.7 & 32791 & 47.0 & 85345 & 5567 \\
\hline Canido & 2.0 & 2895 & & & 2.0 & 2895 & \\
\hline Cariño & 3.8 & 5556 & 1.2 & 3562 & 5.0 & 9118 & 3901 \\
\hline Cedeira & 4.3 & 6177 & 6.7 & 20650 & 11.0 & 26828 & 24216 \\
\hline Celeiro & 8.1 & 11697 & 3.9 & 12019 & 12.0 & 23717 & 1103 \\
\hline Combarro & 9.3 & 13524 & 3.7 & 11215 & 13.0 & 24739 & \\
\hline Corcubion & 7.3 & 10562 & 2.7 & 8290 & 10.0 & 18852 & \\
\hline Corme & 3.0 & 4342 & & & 3.0 & 4342 & \\
\hline Espasante & 2.7 & 3925 & 0.3 & 883 & 3.0 & 4809 & 1138 \\
\hline Ferrol & 5.5 & 8004 & 1.5 & 4510 & 7.0 & 12514 & \\
\hline Finisterre & 11.0 & 15989 & 3.0 & 9059 & 14.0 & 25048 & 27843 \\
\hline Foz & 4.0 & 5790 & & & 4.0 & 5790 & 422 \\
\hline Isla de Arousa & 12.1 & 17531 & 3.9 & 11925 & 16.0 & 29457 & 20177 \\
\hline Laxe & 11.4 & 16470 & 0.6 & 1904 & 12.0 & 18374 & 12840 \\
\hline Lira & 7.6 & 10995 & 0.4 & 1237 & 8.0 & 12233 & 297 \\
\hline Lorbe & 3.0 & 4306 & 3.0 & 9280 & 6.0 & 13585 & \\
\hline Malpica & 9.7 & 14076 & 4.3 & 13113 & 14.0 & 27189 & 3975 \\
\hline Marin & 4.9 & 7041 & 2.1 & 6551 & 7.0 & 13591 & 5443 \\
\hline Mera & 3.0 & 4342 & & & 3.0 & 4342 & \\
\hline Miño & 1.0 & 1447 & 2.0 & 6135 & 3.0 & 7582 & \\
\hline Moaña & 17.4 & 25136 & 1.6 & 5011 & 19.0 & 30147 & 6781 \\
\hline Mugardos & 2.0 & 2895 & & & 2.0 & 2895 & \\
\hline Muros & 9.5 & 13800 & 0.5 & 1428 & 10.0 & 15228 & 15886 \\
\hline Muxia & 5.9 & 8576 & 3.1 & 9432 & 9.0 & 18008 & 2456 \\
\hline Noia & 12.5 & 18125 & 0.5 & 1465 & 13.0 & 19590 & \\
\hline O Barqueiro & 1.6 & 2352 & 0.4 & 1150 & 2.0 & 3502 & \\
\hline O Grove & 25.8 & 37311 & 9.2 & 28287 & 35.0 & 65598 & 65395 \\
\hline O Pindo & 1.6 & 2376 & 0.4 & 1099 & 2.0 & 3475 & \\
\hline O Vicedo & 0.7 & 951 & 0.3 & 1052 & 1.0 & 2003 & \\
\hline Palmeira & 3.9 & 5643 & 1.1 & 3377 & 5.0 & 9020 & \\
\hline Panxon & 1.0 & 1447 & & & & 1.0 & 1447 \\
\hline Pontedeume & 1.3 & 1873 & 0.7 & 2165 & & 2.0 & 4038 \\
\hline Pontevedra & 7.0 & 10132 & & & & 7.0 & 10132 \\
\hline Porto do Son & 17.3 & 24995 & 0.7 & 2243 & 18.0 & 27238 & 12997 \\
\hline Portonovo & 6.8 & 9868 & 6.2 & 18964 & 13.0 & 28832 & 48728 \\
\hline Portosin & 5.0 & 7237 & & & 5.0 & 7237 & 34 \\
\hline Puebla del Caramiñal & 3.0 & 4378 & 1.0 & 2992 & & 4.0 & 7369 \\
\hline Raxo & 1.7 & 2449 & 0.3 & 944 & & 2.0 & 3393 \\
\hline Redondela & 48.8 & 70702 & 1.2 & 3533 & 50.0 & 74235 & 13036 \\
\hline Rianxo & 17.7 & 25574 & 0.3 & 1015 & 18.0 & 26589 & 9285 \\
\hline Ribadeo & 1.8 & 2661 & 1.2 & 3562 & 3.0 & 6224 & 4732 \\
\hline Ribeira & 25.1 & 36300 & 1.9 & 5890 & 27.0 & 42190 & 110902 \\
\hline Sada - Fontan & 6.4 & 9301 & 5.6 & 17099 & 12.0 & 26399 & 18950 \\
\hline San Cibrao & 4.0 & 5790 & & & 4.0 & 5790 & 28657 \\
\hline Sanxenxo & 4.4 & 6351 & 1.6 & 4945 & 6.0 & 11296 & \\
\hline Vigo & 3.0 & 4342 & & & 3.0 & 4342 & 458119 \\
\hline Vilaboa & 2.8 & 4095 & 1.2 & 3591 & & 4.0 & 7686 \\
\hline Vilanova de Arousa & 10.7 & 15495 & 4.3 & 13172 & & 15.0 & 28668 \\
\hline $\begin{array}{l}\text { Vilaxoan } \\
1213\end{array}$ & 7.0 & 10132 & 3.0 & 9202 & & 10.0 & 19334 \\
\hline Total37 & 501 & 725837 & 116 & 354345 & 617 & 1080182 & 1086474 \\
\hline Total Galicia & 600 & 868710 & 141 & 431918 & 741 & 1300627 & \\
\hline
\end{tabular}



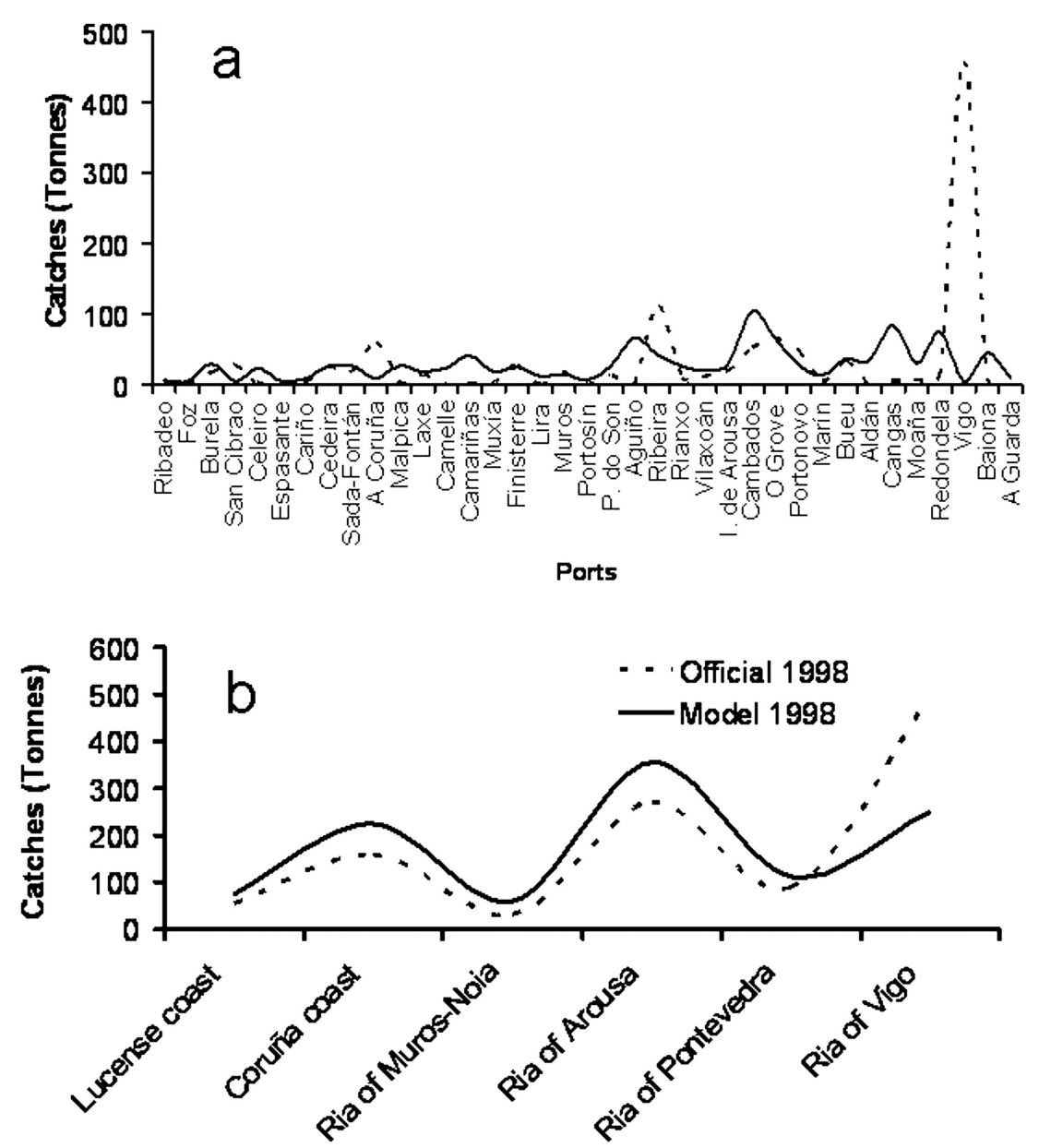

FIG. 3. - Comparison between model total catch and reported catch from fishermen's associations for 1998. (a) Individual catches for the 37 Galician ports. (b) Catches grouped into the coastal areas showed in Figure 1, according to the hypothesis that some landings were trucked to other ports for economic reasons.

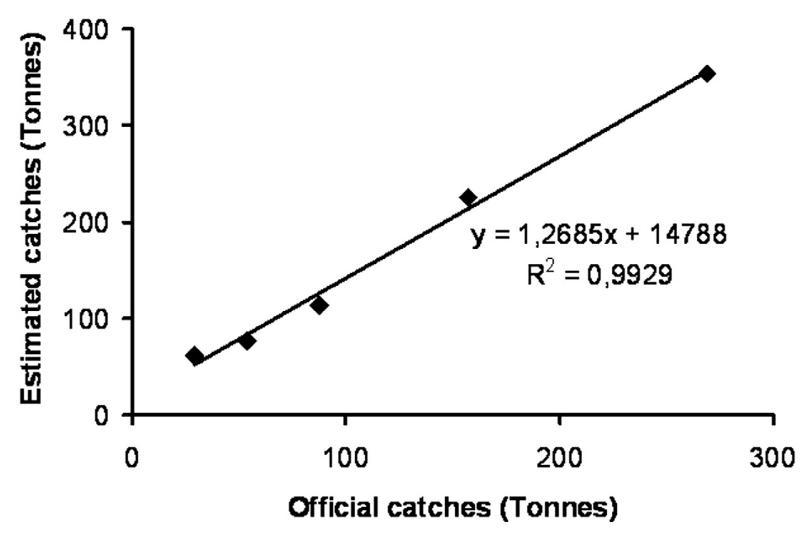

FIG. 4. - Correlation between observed and predicted total catches for cuttlefish, grouping catches into the coastal areas showed in Figure 1. The Ría of Vigo zone was eliminated from this figure due to the high data variability.

\section{DISCUSSION}

The cuttlefish fishery is a widespread activity in several European countries (Coelho and Nunes, 1989; Dunn, 1999; Denis and Robin,
2001; Jereb and Ragonese, 1989; Madelaine and Aovad, 1989; Anonymous, 1998; Wang et al., 2003). France and the United Kingdom obtain the main cuttlefish catches in Atlantic waters, with total catches reaching nearly 18,000 t (Denis and Robin, 2001). In Galicia, according to official data (Xunta de Galica, 2005), the cuttlefish fishery is of great socioeconomic importance, generating a first sale value of over 2 million euros per year. However, only a limited study by Arnaiz et al. (2002) on the small-scale gillnet fishery in the inner part of the Ría of Vigo has been published. Some statistics about cuttlefish landings can be found, but no detailed description of the fishery is available. The particular characteristics of this small-scale fishery, together with the dispersion and unsuitability or non-existence of data on catch and effort, make interviewing fishermen a powerful tool for providing a large amount of useful information for fisheries assessment 
(Simón et al., 1996; Neis et al., 1999; Perry et al., 1999; Young et al., 2006).

Due to the great complexity of Galician fisheries, a major problem was estimating the real number of vessels harvesting cuttlefish in a given area or landing in a specific port. In this respect, the methodology developed here seems to be the most effective procedure for obtaining an accurate estimate of the number of vessels operating in Galician gillnet fishery.

This study found a marked seasonality of catches, with two fishing seasons for the gillnet fishery: $81 \%$ of the total Galician cuttlefish fleet had a short fishing season while $19 \%$ of the fleet had an extended fishing season. According to our data, vessels operating in the inner part of the Ria of Vigo were mainly short season vessels. For 1999 and 2000, Arnaiz et al. (2002) found a similar short season activity and estimated a similar CPUE for this fishery to that obtained from the present model. In Portugal, Coelho and Nunes (1989) observed two peaks of cuttlefish catches in spring and autumn. In French Atlantic coastal, English Channel and adjacent waters, $S$. officinalis catches occur all year round, with a peak in winter (Dunn, 1999; Denis and Robin, 2001; Wang et al., 2003).

The characteristic problems that can be found in the use of interview-based methods such as the Gómez-Muñoz model were avoided in this study by following the Rocha et al. (2004) methodology. As indicated in Rocha et al (2004), original data are based on the appraisals and memory of fishers and each fisher may have a different interpretation of the variables used in the model. For these reasons, the model was applied only in cases in which a minimum number of interviews from fishers could be obtained, and variables and parameters were estimated by applying the Gómez-Muñoz model with statistical improvements described in Rocha et al. (2004).

Discrepancies between official landings and those estimated by the model ranged from 0.3 to $99.9 \%$ at the 37 selected ports (Table 3 and Fig. 3a). No doubt this was partly because some vessels changed their port of landing during the year of study, and partly because landings at some ports were trucked to other ports for economic reasons and registered as having been landed there (Rocha et al., 2004). However, the effect of these biases was minimised, because the total catch was estimated for the whole fleet rather than the fleet representing each port. Also, if model and official catches are grouped into coastal areas (showed in Figure 1), discrepancies between the two estimations are minimised (Figs. 3b and 4). The Ria of Vigo zone shows the highest discrepancies between observed and predicted values. This may be because Vigo is one of the main fishery and commercial ports in Spain, so it is the major centre of attraction for cuttlefish trucked from other ports.

If discrepancies concerning local catches are ignored, official total landings registered at the 37 ports are not significantly different $(0.55 \%$, $p>0.05$ ) from those estimated by the model. In this case, it must be noted that these ports represent about $83.1 \%$ of the total Galician cuttlefish catches. These results confirm observations of Gómez-Muñoz (1990), Simón et al. (1996) and Rocha et al. (2004), indicating that this methodology is suitable for estimating reported, unreported and misreported catch and effort data without great difficulties and cost. As in Galician fisheries for Lophius spp. (Rocha et $a l ., 2004)$, part of the discrepancies observed between the Gómez-Muñoz model estimations and the fish market data could represent landings that do not pass through the official market (unreported catches).

The proposal outlined by Freire and GarcíaAllut (2000) and Freire et al. (2002) for researching and developing sustainable strategies and new polices to be applied by the Galician government is an alternative framework that must be developed in the future. The model applied in this paper can be used as an independent tool for estimating catch and effort in any given fishery, and for testing the reliability of the landing statistics, which is a key point when there are no catch and CPUE statistics, as occurs in the small-scale cuttlefish fishery.

\section{ACKNOWLEDGEMENTS}

We thank J. Castro, M.T. Fernández, E. Ledo and M.C. Rodríguez for their technical support, and all the fishers, skippers, and other members of the fishing fraternity who allowed them- 
selves to be interviewed during the study. The constructive comments of the scientific editor of this paper and two anonymous referees are acknowledged. The research was funded by the EU Study Projects CE 97/0107 and CFP 99/063. J. Otero was supported by a grant from the Diputación de Pontevedra.

\section{REFERENCES}

Anonymous. - 1998. Report of the working group on cephalopod fisheries and life history. ICES C.M. 1998/G: 7, 40 pp.

Arnaiz, R., E. Rodríguez, F.A. Quinteiro, R. Bañon, J.M. Campelos, F. Lamas, A. Gancedo, M. García and G. Costas. - 2002. La pesquería de Sepia (Sepia officinalis) con trasmallos en la ensenada de san Simón (Ría de Vigo) 1999-2000. Los Recursos Marinos de Galicia. Serie Técnica, 2.

Coelho, M.L. and C. Nunes. - 1989. The fishery of Sepia officinalis in Portugal. In: E. Boucaud-Camou (ed.), La Seiche, p. 348. Université de Caen, Caen.

Denis, V. and J.P. Robin. - 2001. Present status of the French Atlantic fishery for cuttlefish (Sepia officinalis). Fish. Res., 52: $11-22$.

Dunn, M.R. - 1999. Aspects of the stock dynamics and exploitation of cuttlefish, Sepia officinalis (Linnaeus, 1758), in the English Channel. Fish. Res., 40: 277-293.

Durán-Neira, C. - 1991. Caladeros de pesca del litoral gallego. Fundación Caixa Galicia, A Coruña, Spain.

Freire, J. and A. García-Allut. - 2000. Socioeconomic and biological causes of management failures in European artisanal fisheries: the case of Galicia (NW Spain). Mar. Policy, 24: 375-384.

Freire, J., C. Bernárdez, A. Corgos, L. Fernández, E. GonzálezGurriarán, M.P. Sampedro and P. Verísimo. - 2002. Management strategies for sustainable invertebrate fisheries in coastal ecosystems of Galicia (NW Spain). Aquat. Ecol., 36: 41-50.

Gómez-Muñoz, V.M. - 1990. A model to estimate catches from a short fishery statistics survey. Bull. Mar. Sci., 46: 719-722.

Guerra, A. - 1989. The exploitation of cuttlefish. In: E. BoucaudCamou (ed.), La Seiche, pp. 343-344. Université de Caen, Caen.

Guerra, A. - 2006. Ecology of Sepia officinalis. Vie Milieu, 56(2): 97-107.

Hoening, J.M., C.M. Jones, K.H. Pollock, D.S. Robson and D.L. Wade. - 1997. Calculation of catch rate and total catch in roving surveys of anglers. Biometrics, 53: 306-317.

Jereb, P. and S. Ragonese. - 1989. The role played by Sepia officinalis Linnaeus, 1758 in the southern Sicilian fisheries. In: E. Boucaud-Camou (ed.), La Seiche, p. 349. Université de Caen, Caen.

Kirchner, C.H. and J.E. Beyer, 1999. Estimation of total catch of
Silver Kob Argyrosomus inodorus by recreational shoreanglers in Namibia using a roving-roving creel survey. S. Afr. J. Mar. Sci., 21: 191-199.

Madelaine, B. and T. Aouab. - 1989. Cuttlefish trapping fishery on Calvados coasts. In: E. Boucaud-Camou (ed.), La Seiche, p. 350. Université de Caen, Caen.

Neis, B., D.C. Schneider, L. Felt, R.L. Haedrich, J. Fischer and J.A. Hutchings. - 1999. Fisheries assessment: what can be learned from interviewing resource users? Can. J. Fish. Aquat. Sci., 56: 1949-1963.

Otero, J., F. Rocha, A.F. González, J. Gracia and A. Guerra. - 2005. Modelling artisanal coastal fisheries of Galicia (NW Spain) based on data obtained from fishers: the case of Octopus vulgaris. Sci. Mar., 69(4): 577-585.

Perry, R.I., C.J. Walters and J.A. Boutiller. - 1999. A framework for providing scientific advice for the management of new and developing invertebrate fisheries. Rev. Fish Biol. Fisher., 9: 125-150.

Pollock, K.H., J.M. Hoening, C.M. Jones, D.S. Robson and C.J. Greene. - 1997. Catch rate estimation for roving and access point surveys. N. Am. J. Fish. Manag., 17: 11-19.

Rocha, F., J. Gracia, A.F. González, C.M. Jardón and A. Guerra. 2004. Reliability of a model based on a short fishery statistics survey: application to the Northeast Atlantic monkfish fishery. ICES J. Mar. Sci., 61: 25-34.

Royer, J., Pierce, G.J., Foucher, E. and J.P. Robin - 2006. The English Channel stock of Sepia officinalis: modelling variability in abundance and impact of the fishery. Fish. Res., 78: 96-106.

Simón, F., F. Rocha and A. Guerra. - 1996. The small-scale squid hand-jig fishery off the northwestern Iberian Peninsula: application of a model based on a short survey of fishery statistics. Fish. Res., 25: 253-263.

Tukey, J.W. - 1977. Exploratory Data Analysis. Addison-Wesley Series in Behavioural Sciences, Quantitative Methods, 16. Addison Wesley Publishing Company, Massachusetts, USA.

Wang, J., G.J. Pierce, P.R. Boyle, V. Denis, J.P. Robin and J.M. Bellido. - 2003. Spatial and temporal patterns of cuttlefish (Sepia officinalis) abundance and environmental influences - a case study using trawl fishery data in French Atlantic coastal, English Channel, and adjacent waters. ICES J. Mar. Sci., 60: 1149-1158.

Xunta de Galicia. - 2000. Censo oficial de la flota pesquera de Galicia para 1999. Website: http://www.xunta.es.

Xunta de Galicia. - 2005. Estadísticas de capturas en Galicia. Datos por puerto, fecha y especie. Website: http://www.pescadegalicia.com.

Young, I.A.G., G.J. Pierce, J. Murphy, H.I. Daly and N. Bailey. 2006. Application of the Gómez-Muñoz model to estimate catch and effort in squid fisheries in Scotland. Fish. Res., 78: 26-38.

Zar, J.H. - 1999. Biostatistical Analysis. Prentice Hall, New Jersey.

Received May 20, 2005. Accepted June 29, 2006.

Scient. ed.: G. Pierce.

Published online October 23, 2006. 
